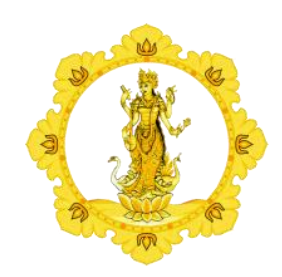

KALANGWAN

JURNAL PENDIDIKAN AGAMA, BAHASA DAN SASTRA

Vol. 9 No. 2 September 2019

\begin{tabular}{|c|c|c|}
\hline p-ISSN : 1979-634X & e-ISSN : 2686-0252 & http://ejournal.ihdn.ac.id/index.php/Kalangwan \\
\hline
\end{tabular}

\title{
RASA BAHASA DALAM BAHASA BALI
}

\author{
Oleh : \\ Gusti Nyoman Mastini \\ Institut Hindu Dharma Negeri Denpasar \\ E-mail: gustinyomanmastini@gmail.com
}

Diterima 12 Juli 2019, direvisi 10 Agustus 2019, diterbitkan 2 September 2019

\begin{abstract}
Rasa bahasa di dalam percakapan menggunakan Bahasa Bali sangatlah penting, karena ketika berbicara jika rasa bahasanya sudah sesuai dengan unggul-ungguling Bahasa Bali akan dapat menimbulkan rasa senang. Tetapi sebaliknya jika rasa bahasanya tidak sesuai dengan anggah-ungguhing, maka akan menimbulkan rasa tidak enak/janggal.

Bahasa Bali jika dilihat dari rasa bahasanya dapat dibagi menjadi 3 yakni (1) Rasa bahasa dalam bentuk kata meliputi : (a) kruna alus mider, (b) kruna alus madia, (c) kruna alus singgih, (d) kruna alus singgih, (e) kruna alus sor, $(f)$ kruna mider, $(g)$ kruna andap, dan (h) kruna kasar. (2) Rasa bahasa dan bentuk kalimat meliputi : (a) lengkara alus singgih, (b) lengkara alus madia, (c) lengkara alus sor, (d) lengkara andap, dan (e) lengkara kasar. (3) Selanjutnya Bahasa Bali dilihat dari rasa bahasanya dibagi menjadi (a) bahasa alus, (b) bahasa madia, (c) bahasa andap, dan (d) bahasa kasar.
\end{abstract}

\section{Keywords: Rasa Bahasa, Bahasa Bali}

\section{PENDAHULUAN}

Masyarakat Bali sampai saat ini masih menggunakan Bahasa Bali, sebagai media komunikasi antar etnis penutur Bahasa Bali, baik dalam situasi formal maupun, tidak formal. Keberadaan Bahasa Bali memiliki variasi yang cukup rumit yang disebabkan karena adanya sor singgih atau anggahungguhing Bahasa Bali karena masyarakat
Bali sampai saat ini masih memenuhi stratifikasi sosial.

Dengan adanya sor singgih atau anggahungguhing Bahasa Bali akan dapat menimbulkan rasa bahasa yang berbeda. Rasa bahasa ketika berbicara menggunakan Bahasa Bali sangatlah penting. Karena ketika berbicara menggunakan Bahasa Bali sangatlah penting. Karena ketika berbicara, 
jika rasa bahasa sudah sempurna atau sudah sesuai dengan anggah-ungguhing Bahasa Bali, maka akan dapat menimbulkan perasaan senang bagi orang yang mendengarkan. Tetapi sebaliknya jika rasa bahasa yang digunakan ketika berbicara tidak sesuai dengan anggah-ungguhing Bahasa Bali, maka akan dapat menimbulkan rasa yang tidak enak atau janggal bagi yang mendengarkan.

Dengan demikian usaha untuk meningkatkan kemampuan berbicara dengan menggunakan anggah-ungguhing Bahasa Bali, adalah rasa bahasa. Rasa bahasa yang harus dipahami meliputi rasa bahasa dari tingkat kata /kruna (Bahasa Bali), karena kata merupakan satuan bahasa terkecil yang memiliki arti, yang menjadi dasar dari tari pembentuk sebuah kalimat.

\section{PEMBAHASAN}

\subsection{Rasa Bahasa dalam Bentuk Kata}

Apabila dilihat dari bentuk katanya rasa bahasa dalam Bahasa Bali dibagi menjadi :

1. Kruna Alus, yang dibagi menjadi 4 bagian :

(1) Kruna alus mider, adalah kruna alus yang rasa bahasanya dapat dipakai untuk menghormati orang yang dihormati baik dari golongan Tri Wangsa maupun golongan Jaba.

Contoh :

- Ida wau rauh saling jawi

- Titiang wau rauh saking jawi

Kata-kata yang bergaris bawah pada kalimat diatas semuanya termasuk kruna alus mider. Jika kata-kata tersebut diganti dengan kata-kata yang lain seperti wau diganti mara, rauh diganti dengan teka, saking diganti dengan uli, jawi diganti dengan jawa, sementara pada kalimat (a) ada kata ida dan kalimat (b) ada kata titiang yang cenderung tergolong kruna alus. Jika kruna alus diikuti dengan alus andap atau kruna kasar, maka akan terasa janggal atau menimbulkan rasa tidak enak bagi yang mendengarkan seperti contoh

- Ida mara teka uli jawa

- Titiang mara teka uli jawa

(2) Kruna Alus Madia

Kruna alus madia adalah kruna alus yang rasa bahasanya berada antara bahasa alus singgih dan bahasa alus sor. Adapun untuk yang memiliki rasa bahasa alus madia adalah : niki, nika, ampun, tiang, ngajeng, sirep dsb.

Contoh :

- tiang ampun ngajeng di warung

- adin tiange dereng ngajeng

(3) Kruna Alus Singgih

Kruna alus singgih adalah kruna alus yang digunakan untuk menghormati orang yang patut dihormati. Kruna alus singgih ini merupakan pelengkap dari kruna alus mider, karena kruna alus singgih tidak memiliki bentuk alus mider. seperti : seda, mobot, ida, ngaksi, maparab, mireng, mantuk, wikan, parab dsb.

Contoh dalam kalimat

- Ida sampun mantuk dibi sore

(4) Kruna Alus Sor

Adalah kruna alus yang digunakan untuk merendahkan diri atau merendahkan orang patut direndahkan. Adapun kata-kata yang tergolong kruna alus sor adalah : padem, budal, matur, mirage, ipun. tambet, wasta, nglungsur, dsb.

Contoh dalam kalimat :

- ipun sampun padem

\section{Kruna Mider}

Rasa bahasa kruna mider jika dibandingkan dengan kruna alus mider sering menimbulkan rasa bimbang, 
karena keduanya dapat digunakan untuk menghormati orang yang patut dihormati, dan dapat juga dijunakan untuk merendahkan diri sendiri atau orang lain. Tetapi kruna mider tidak memiliki bentuk andap (tidak memiliki oposisi). Sedangkan kruna alus mider memiliki bentuk andap. Dengan demikian kruna mider rasa bahasanya sama (netral) untuk semua golongan.

Untuk memperjelas pelentih contoh kalimat dibawah ini

- Ida mambas arit

- ipun numbas arit

- $\quad$ ia meli arit

3. Kruna Andap

Kruna andap juga disebut dengan kata lepas hormat, yang rasa bahasanya biasa (andap) yang biasa digunakan dalam kehidupan sehari-hari

Contoh dalam kalimat : ia suba madaar

4. Kruna Kasar

Kruna kasar adalah kruna / kata yang rasa bahasanya kasar yang lumbrah digunakan ketika dalam suasana marah Contoh dalam kalimat : depang suba ia Bangka

\subsection{Rasa Bahasa dalam Bentuk Kalimat (Lengkara)}

Berdasarkan rasa bahasa, kalimat dalam Bahasa Bali dibagi menjadi 5 bagian yakni :

1. Lengkara Alus Singgih, dibentuk lengkara alus singgih dibentuk oleh kruna alus singgih, kruna alus mider, dan kruna mider

Contoh : Ida kantun mentok

2. Lengkara Alus Madia

Lengkara alus madia dibentuk oleh kruna alus madia, alus mider, kruna mider dan kruna andap

Contoh: Tiang kantun membas katik dumur

Tiang nu numbas katik malu
3. Lengkara Alus Sor

Lengkara alus sor dibentuk oleh kruna alus sor, alus mider, kruna andap dan kruna mider.

Contoh : - ipun kantun nembok

- ipun kantun numbas katik sate

4. Lengkara Andap

Lengkara andap dibentuk oleh kruna andap, dan kruna mider

Contoh : ia majalan ka tegale lakar ngebah punyan tiing

5. Lengkara Kasar

Lengkara kasar dibentuk oleh kruna andap, kruna kasar dan kruna mider

Contoh : suud mamantet, ia magedi langsung medem

\subsection{Rasa Bahasa dalam Bahasa Bali}

Rasa Bali Bahasa Bali dibentuk oleh kruna-kruna dan lengkara-lengkara sebagaimana telah diuraikan diatas. Menurut Ida Bagus Udara Narayana (1984) rasa bahasa dalam Bahasa Bali dibagi menjadi 4 bagian yaitu :

1. Bahasa Alus

Adalah Bahasa Bali yang digunakan untuk menghormati orang patut dihormati baik orang yang diajak bicara ataupun orang yang dhibicarakan Bahasa Bali alus dibentuk oleh kruna alus mider, alus singgih, alus sor kruna mider dan kruna andap.

Contoh : Ainggih ida sane krama banjar sane dahat wangiang titiang, rahina sane benjang titiang nunas ida dane mangda tedun mabusana adat madia, duaning pacang wenten dharma wecana saking Ida Padanda Gede Tianyar.

2. Bahasa Bali Madia

Basa madia adalah Bahasa Bali yang rasa bahasanya tidak terlalu halus dan juga tidak kasar. Bahasa ini digunakan kepada Tri Wangsa, sesame triwangsa atau golongan bawah yang patut dihormati Bahasa Bali madia dibentuk 
oleh kruna alus madia, kruna alus mider, kruna mider dan kruna andap.

Contoh :

ngawit dibi sanja tiang ngayang dini, dereng wenten panggihin tiang anak liwat. Kantos petang gelas tiang nelahang kopi, dereng taler wenten anak rauh.

3. Bahasa Bali Andap/ Kepara/Lumbrah Bahasa Andap adalah Bahasa Bali yang rasa bahasanya tidak hormat atau alus dan juga tidak kasar. Bahasa ini dibentuk oleh kruna andap dan kruna mider. Bahasa andap dapat digunakan oleh semua golongan seperti :

- golongan jaba Bahasa Bali ini digunakan dalam lingkungan pergaulan sehari-hari

- golongan tri wangsa bahasa ini digunakan kepada wangsa yang lebih rendah

Contoh: anak ngroko patuh buka make madaar base ngrokone ento tuah anggona pararasan dogen ngrokone ento makelokelo sinah ngranayang sakit

4. Bahasa Bali Kasar

Bahasa kasar adalah bahasa yang digunakan dalam suasana keakraban dan suanasa kemarahan.

Bahan kasar dibentuk oleh : kruna andap, mider dan kruna kasar.

Contoh : yadiastun icang tiwas, icing konden taen tendeh-tendeh ngidih amah-amahan teken nyai. Yen sing sangkaning bapan wakene, mirib nyai tusing nyidang mamantet buka jani.

\section{SIMPULAN}

Berdasarkan apa yang telah diuraikan dapat disimpulkan

1. Rasa bahasa dalam bentuk kata dapat dibagi : (1) kruna alus mider, (2) kruna alus madia, (3) kruna alus singgih, (4) kruna alus sor, kruna mider, (6) kruna andap, (7) kruna kasar.

2. Rasa bahasa dalam bentuk kalimat dapat dibagi menjadi : (1) lengkara alus singgih, (2) lengkara alus madia, (3) lengkara alus sor, (4) lengkara andap, dan (5) lengkara kasar.

3. Rasa bahasa Bahasa Bali dibagi menjadi (1) bahasa alus, (2) bahasa madia, (3) bahasa madia, (4) bahasa andap, dna (4) bahasa kasar.

\section{DAFTAR PUSTAKA}

Bagus Dkk, I Gusti Ngurah. 1978/1979. Unda Usuk Bahasa Bali. Denpasar: Proyek Penelitian Bahasa Indonesia dan Daerah Pusat Pembinaan dan Pengembangan Bahasa. Departemen Pendidikan dan Kebudayaan.

J. Kersthen. 1970. Warna-warna Bahasa Bali. dimuat dalam Tata Bahasa Bali. Ende Flores : Arnold Dus.

Rai Sudarta, Tjokorda. 1994. Tata Krama Bahasa Bali dalam Majalah Manguri. No. 2 Wahana Komunikasi dan Infromasi Mahasiswa Sastra Daerah Fakultas Sastra UNUD.

Suasta Ida Bagus Made. 1994. Kemampuan Berbicara berdasarkan Anggahungguhing Basa Bali. Bahan Penataran Bahasa Bali untuk Guruguru SLTP, SLTA Se-Bali 12 s.d 15 Oktober 1994 di Denpasar. 1997. "Berpidato dengan Bahasa Bali" Denpasar : Jurusan Sastra Daerah Fakultas Sastra Universitas Udayana.

Udara Narayana, Ida Bagus. 1983. "Anggahungguhing Basa Bali dan Peranannya sebagai Alat Komunikasi bagi Masyarakat Bali”. Denpasar: Fakultas Sastra Universitas Udayana.

Tinggen, I Nengah. 1986. Sor-Singgih Basa Bali. Istilah Indonesia-Bali. Singaraja: Rhika Dewa. 